\title{
RC スラブが負曲げモーメントを受ける場合の耐火性能に関する研究 STUDY ON FIRE RESISTANCE OF REINFORCED CONCRETE SLAB UNDER THE NEGATIVE BENDING MOMENT
}

\author{
西村 俊 彦*
}

\section{Toshihiko NISHIMURA}

This paper describes experimental and analytical studies on the fire resistance of a reinforced concrete slab under the negative bending moment. As the result of fire resistance tests, it became clear that the reinforced concrete slab under the negative bending moment had the outstanding performance for the fire heating. The bar arrangement of main reinforcement and slab thickness influence the fire resistance greatly.The analysis result was well in agreement with the experimental results. Parameter study was performed and the influence of the bar arrangement and slab thickness on the fire resistance became clear.

Keywords : fire resistance, reinforced concrete slab, negative bending moment,

fire resistance test under load, thermal stress and deformation analysis

耐火性能、R C スラブ、負曲げモーメント、載荷加熱試験、熱弹塑性解析

\section{1. はじめに}

筆者らはこれまで鉄筋コンクリート造床スラブ（以下、 R C スラ ブ）の耐火性能に関する研究を進めてきた 1) 2)。文献 1 では、正曲げ モーメント (スラブ下端に引張応力を発生させる曲げモーメント) を受けるR Cスラブを対象に、載荷加熱実験と数值解析を行い、耐 火性能を明らかにすると共に、火災耐力評価式を提案した。

一方、建物で一般に用いられるR C スラブは端部を梁によって拘 束されるため、スラブ中央部には正曲げモーメントが、スラブ端部 には負曲げモーメント（スラブ上端に引張応力を発生させる曲げモ ーメント）が発生し、スラブスパン方向に正曲げ域と負曲げ域が同 時に形成される（図 1)。そして火災時には、曲げ耐力の低下によっ て端部と中央部に塑性ヒンジが形成され崩壊に至る。このため、R Cスラブの耐火性能を評価するには、正曲げモーメントを受ける中 央部と併せて、負曲げモーメントを受ける端部についても火災時耐 力を把握する必要がある。

耐火性能検証法（平成 12 年建設省告示第 1433 号）3)では、負曲 げモーメントを受ける R C スラブ端部の火災耐力評価式を提案して いる。 $500^{\circ} \mathrm{C}$ 以上の断面を無効帯とみなし、 $500^{\circ} \mathrm{C}$ 以下の有効断面に 対して火災時耐力を計算する略算法であり、安全率を見込む代わり に、簡易に火災時耐力を計算出来るという利点を有している。実務 の設計においては有用なツールとなっているが、火災時の性状を適
切に考慮したものとはなっておらず、耐火性能を過小評価する傾向 がある。このため、火災継続時間が長い場合や荷重条件が厳しい場 合などは配筋の変更が必要になることがあり、火災時の性状を適切 に考慮した火災耐力評価法が求められている。耐火性能検証法に代 わる火災耐力評価法を得るためには、負曲げモーメントを受ける $\mathrm{R}$ Cスラブ端部が火災によって破壊に至る挙動を明らかにし、火災時 耐力を定量的に把握する必要がある。

負曲げモーメントを受ける R C 部材（梁・床）に関する既往の研 究として、文献 4 では小断面の R C 梁試験体に圧縮側から加熱を与 え、理論解との比較検討を行うことで、火災時の変形挙動と耐力に 関する知見が得られている。文献 5,6 では、材端拘束を受ける R C 部材 (梁・床) を対象に数值解析による検討が行われている。材端

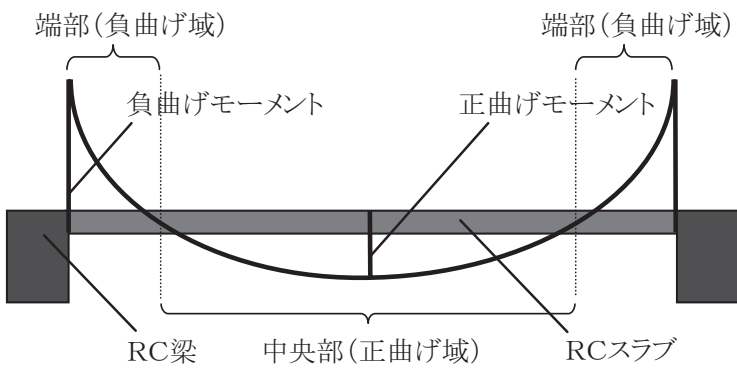

図 1 正曲げ域と負曲げ域
* 竹中工務店技術研究所 主任研究員 ·工修 (東京理科大学大学院理工学研究科博士課程建築学専攻在籍)
Research and Development Institute, Takenaka Corporation, M. Eng. (Doctoral Course Student, Dept. of Architecture, Graduate School of Science and Technology, Tokyo University of Science) 
を拘束された R C 曲げ部材が加熱を受けると、端部の拘束曲げモー メントが中央部の引張側曲げモーメントを打ち消すように作用し、 材端部の負曲げ耐力と中央部の正曲げ耐力の和が、外力により生じ る作用曲げモーメントの值まで低下したときに、両端及び中央部に 塑性ヒンジが形成され破壊に至ることが示されている。これらの文 献によって、R Cスラブの耐火性能に関する貴重な知見が得られて いるが、負曲げモーメントを受ける R C スラブが火災加熱によって 破壊に至る挙動については不明な点が多く、火災時耐力を定量的に 把握するところまでは至っていない。

そこで本研究では、負曲げモーメントを受ける R C スラブの火災 時の挙動を明らかにし、火災時耐力を定量的に把握することを目的 として、実験と数值解析による検討を行った。2 章では、実大サイズ の試験体に対する載荷加熱実験を行い、負曲げモーメントを受ける R C スラブの耐火性能を検討した。3 章では数值解析を行い、負曲げ モーメントを受けるR C スラブの火災時における破壊挙動と火災時 耐力を検討した。

\section{2. 負曲げモーメントを受けるR Cスラブの載荷加熱実験 \\ 2. 1 試験体}

負曲げモーメントを受ける R C スラブの耐火性能を検討するため 載荷加熱実験を実施した。図 2 に試験体を示す。支持梁の両側に片 持ちスラブを接合した試験体で図 1 のスラブ端部をモデル化した。 図 1 のモデルは加熱を受けると、両端を拘束されることで拘束曲げ モーメントが発生するが、ここではその影響は考慮せず、支持点を ピン支持として加熱中は終始試験体に一定の負曲げモーメントが生 じるモデルとした。支持梁は幅 $400 \mathrm{~mm} \times$ せい $600 \mathrm{~mm}$ の R C 梁とし、こ の両側に長さ $1400 \mathrm{~mm}$ の一方向配筋されたR Cスラブを接続させた。 スラブ幅及び梁長さは共に $1000 \mathrm{~mm}$ とした。なお、支持梁である R C 梁については、加熱による強度と剛性の低下及び熱変形の影響を除 くため、加熱表面をセラミックブランケットで耐火被覆した。この 実験では、負曲げモーメントを受ける R C スラブの破壊時の挙動と 耐力を把握することを目的として、試験体が破壊するまで加熱を続 ける計画とした。実験変数は、スラブ厚、配筋、載荷荷重とした。 試験体一覧を表 1 に示寸。
表 1 試験体一覧

\begin{tabular}{|c|c|c|c|c|c|}
\hline 試験体名 & $\begin{array}{c}\begin{array}{c}\text { スラブ厚 } \\
(\mathrm{mm})\end{array} \\
\text { (1) }\end{array}$ & 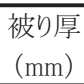 & 下端主筋 & 上端主筋 & $\mathrm{M} / \mathrm{Mu}$ \\
\hline 試験体1 & 150 & \multirow{5}{*}{30} & \multirow{5}{*}{$\begin{array}{c}\mathrm{D} 13 @ 200 \\
(5-\mathrm{D} 13)\end{array}$} & \multirow{3}{*}{$\begin{array}{c}\text { D13@200 } \\
\text { (5-D13) }\end{array}$} & 0.45 \\
\hline 試験体2 & 150 & & & & \\
\hline 試験体3 & 200 & & & & 0.87 \\
\hline 試験体4 & \multirow{2}{*}{150} & & & D13@100 & \\
\hline 試験体5 & & & & (9-D13) & 0.99 \\
\hline
\end{tabular}

載荷荷重は、図 2 に示寸梁縁位置でスラブに生じる曲げモーメン 卜 M と (1) 式で計算される常温時の終局曲げ耐力 Mu の比（以下、荷 重比）で設定した。

$$
\begin{aligned}
& \mathrm{M}_{\mathrm{u}}=0.9 \mathrm{a}_{\mathrm{t}} \cdot \sigma_{\mathrm{y}} \cdot \mathrm{d} \\
& \text { ここに、 } \mathrm{M}_{\mathrm{u}} \quad \text { : 常温時の終局曲げ耐力 }\left(\mathrm{kN} \cdot \mathrm{m} \cdot 10^{-6}\right) \\
& \mathrm{a}_{\mathrm{t}} \quad \text { : 上端主筋の断面積 }\left(\mathrm{mm}^{2}\right) \\
& \sigma_{\mathrm{y}}: \text { 上端主筋の降伏強度 }\left(\mathrm{N} / \mathrm{mm}^{2}\right) \\
& \mathrm{d} \text { : 上端主筋重心から圧縮側最外縁までの距離 }(\mathrm{mm})
\end{aligned}
$$

上端主筋の降伏強度 $\sigma_{\mathrm{y}}$ は鉄筋の引張試験から得られた $0.2 \%$ オ セット強度(表 5) とした。試験体 1 と試験体 2 は、スラブ厚を $150 \mathrm{~mm}$ 、 上下主筋をD13@200 として荷重比を変化させた。荷重比 0.45 の試験 体 1 に対し実験を行った結果、極めて高い耐火性能を示したことか ら（詳細は2.4.2 に示す）、試験体 2 は、加熱中に試験体を破壊させ るため、荷重比を構造設計上の長期許容曲げモーメント $(\mathrm{M} / \mathrm{Mu}=0.66)$ を上回る高い值 $(\mathrm{M} / \mathrm{Mu}=0.87)$ に設定した。試験体 3 は、主筋配筋と 荷重比を試験体 2 と同じとし、スラブ厚を $200 \mathrm{~mm}$ とした。試験体 4 は、スラブ厚と荷重比を試験体 2 と同じとし、上端主筋をD13@100 とした。試験体 5 はスラブ厚と主筋配筋を試験体 4 と同じとし、荷 重比を変化させた。

\section{2 使用材料}

コンクリートの使用材料を表 2 に、調合を表 3 に、材料特性を表 4 に示す。スラブ鉄筋はいずれも SD295A とした。スラブ主筋である D 13 の引張試験結果を表 5 に示す。

\section{3 実験方法}

竹中工務店技術研究所の載荷加熱用耐火試験炉を用いて耐火実験 を実施した。実験方法を図 3 に示す。而付試験炉の上部に試験体を

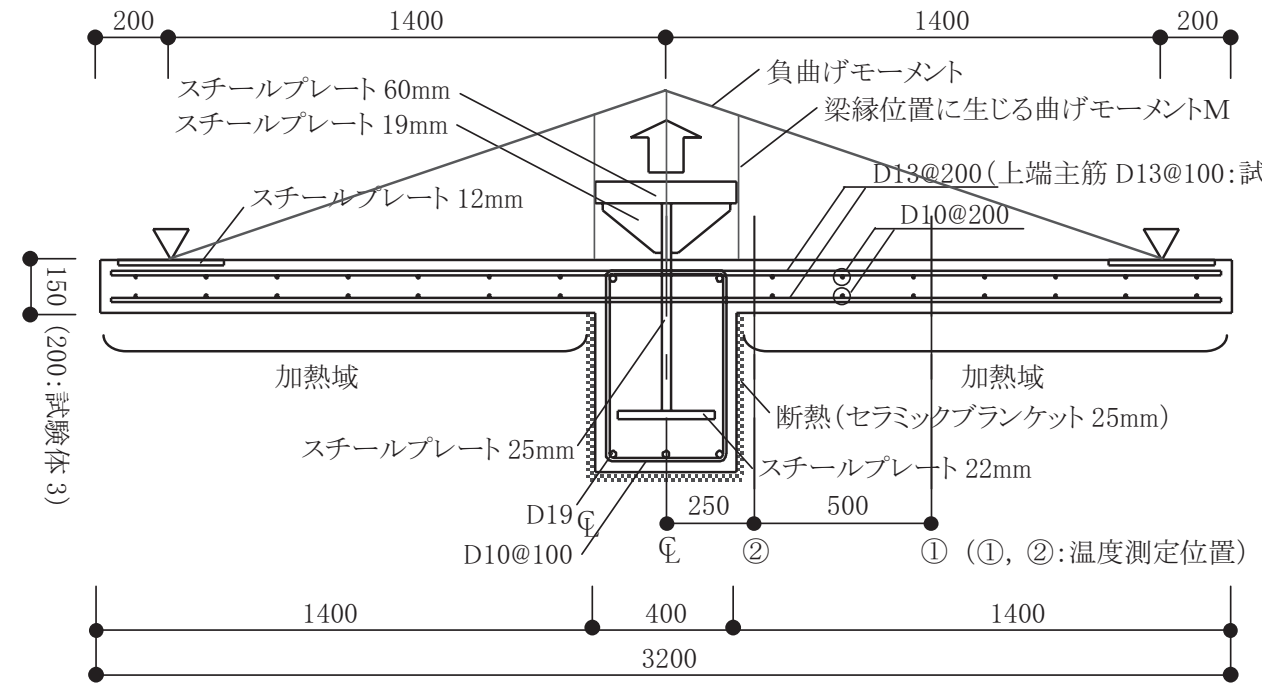

（長さ方向断面）
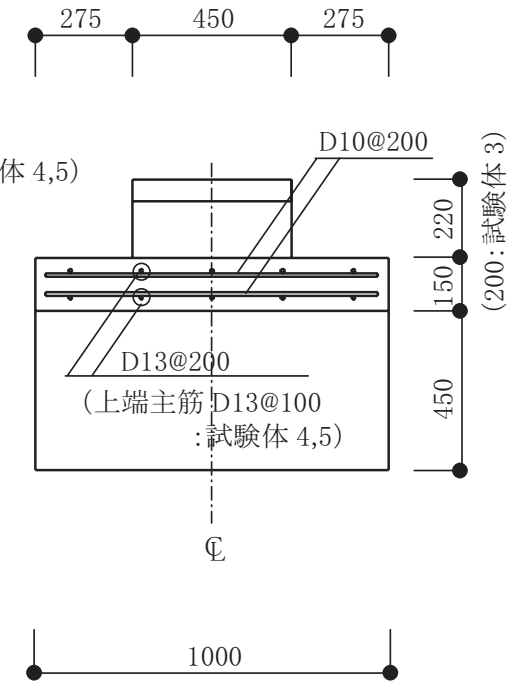

（幅方向断面） 
設置し、両端を支持した状態で試験体の中央部を油圧ジャッキによ って上に引き上げることでR C スラブに負曲げモーメントを与えた。 載荷荷重は、梁縁位置でスラブに生じる曲げモーメントM（図 2）と 曲げ耐力 Mu の比が表 1 に示寸值となるよう設定した。所定の荷重を 保持した状態で IS0-834 に規定された標準加熱温度曲線に従い、試

表 2 コンクリートの使用材料

\begin{tabular}{|c|c|c|c|}
\hline & 種類 & 産地 & $\begin{array}{c}\text { 密度 (表乾) } \\
\mathrm{g} / \mathrm{cm}^{3}\end{array}$ \\
\hline \multirow{2}{*}{ 細骨材 } & 陸砂 & 鹿島 & 2.56 \\
\hline & 砕砂 & 岩瀬 & 2.62 \\
\hline 粗骨材 & 砕石 & 岩瀬 & 2.65 \\
\hline セメント & \multicolumn{3}{|c|}{ 普通ポルトランドセメント } \\
\hline 混和剂 & \multicolumn{3}{|c|}{ AE減水剂 標準形(ポゾリスNo.70) } \\
\hline
\end{tabular}

表 3 コンクリートの調合

\begin{tabular}{|c|c|c|c|c|c|c|c|}
\hline 目標強度 & 水セメント比 & 細骨材率 & \multicolumn{5}{|c|}{ 単位量 $\mathrm{kg} / \mathrm{m}^{3}$} \\
\hline $\mathrm{N} / \mathrm{mm}^{2}$ & $\%$ & $\%$ & 水 & セメント & 細骨材 & 粗骨材 & 混和鼡 \\
\hline 24 & 78.0 & 47.3 & 172 & 221 & 866 & 996 & 2.365 \\
\hline
\end{tabular}

表 4 コンクリートの材料特性

\begin{tabular}{|c|c|c|c|c|}
\hline $\begin{array}{c}\text { 圧縮強度 } \\
\left(\mathrm{N} / \mathrm{mm}^{2}\right)\end{array}$ & $\begin{array}{c}\text { 引張強度 } \\
\left(\mathrm{N} / \mathrm{mm}^{2}\right)\end{array}$ & $\begin{array}{c}\text { 弾性係数 } \\
\left(\mathrm{N} / \mathrm{mm}^{2}\right)\end{array}$ & 比重 & $\begin{array}{c}\text { 含水率 } \\
(\%)\end{array}$ \\
\hline 26.37 & 2.76 & $2.655 \times 10^{4}$ & 2.23 & 5.8 \\
\hline
\end{tabular}

表 5 鉄筋の機械的性質

\begin{tabular}{|c|c|c|c|c|}
\hline 鋼材種 & $\begin{array}{c}\text { 降伏強度 } \\
\left(\mathrm{N} / \mathrm{mm}^{2}\right)\end{array}$ & $\begin{array}{c}\text { 弾性係数 } \\
\left(\mathrm{N} / \mathrm{mm}^{2}\right)\end{array}$ & $\begin{array}{c}\text { 引張強度 } \\
\left(\mathrm{N} / \mathrm{mm}^{2}\right)\end{array}$ & $\begin{array}{c}\text { 伸び } \\
(\%)\end{array}$ \\
\hline $\mathrm{SD} 295 \mathrm{~A}$ & 372 & $19.2 \times 10^{4}$ & 536 & 20.4 \\
\hline
\end{tabular}
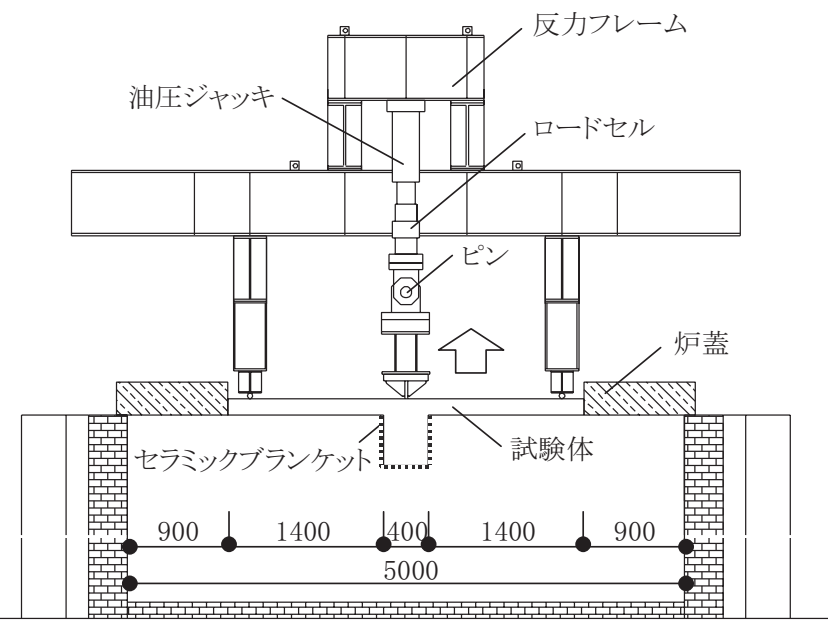

図 3 実験方法

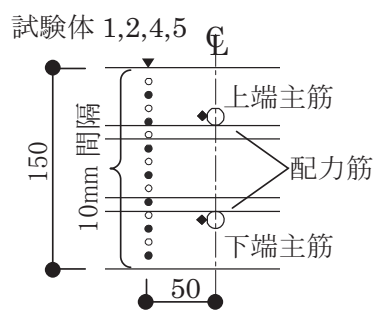

$\checkmark$ : 主筋温度

$\boldsymbol{\nabla}$ : 裏面温度 (位置(1)のみ)

・ :コンクリート温度 (位置(1)・(2)共通)

○:コンクリート温度 (位置(1)のみ)

図 4 温度測定位置 (試験体の幅方向断面)
験体が破壊に至るまで加熱を続けた。なお、今回使用した耐火試験 炉の能力的な理由から、4 時間の加熱を与えても破壊に至らなかった 場合は、耐火試験炉の状態に応じて適宜加熱を終了した。試験体 1 は 332 分、試験体 2 は 315 分、試験体 3 は 270 分まで加熱しても試 験体が破壊しなかったため、加熱終了後、試験体が破壊するまで荷 重を増加させ、破壊時の荷重を測定した。

実験時は、加熱温度、内部コンクリート温度、主筋温度、非加熱 側表面温度（以下、裏面温度）、載荷荷重、加力位置と支持点の鈆直 変位を測定した。内部コンクリート温度と主筋温度は、困 2 に示す 位置(1)及び位置(2)で、裏面温度は位置(1)で K 熱電対を用いて測定し た。熱電対の断面内における設置位置を図 4 に示す。位置(1)は加熱 面から $10 \mathrm{~mm}$ 間隔で、位置(2)は $20 \mathrm{~mm}$ 間隔で熱電対を設置した。荷重 は油圧ジャッキの下側に取り付けたロードセルを用いて測定した。

\section{4 実験結果}

\section{4.1 温度測定結果}

スラブ厚を $150 \mathrm{~mm}$ にした試験体のコンクリート温度測定結果とし て加熱時間が最も長かった試験体 1 の測定結果を図 5 (困 2 に示す温 度測定位置(1)）と図 6 （図 2 に示す温度測定位置(2)）に、スラブ厚を $200 \mathrm{~mm}$ とした試験体 3 のコンクリート温度測定結果を図 7 （温度測定 位置(1)）と図 8（温度測定位置(2)）に示す。また、主筋温度の測定結 果を図 9（温度測定位置(1)）と図 10（温度測定位置(2)）に示寸。

梁縁位置近傍（温度測定位置(2)）は加熱中央部（温度測定位置(1)） に比べ温度が低くなる傾向が見られた。これはスラブが受けた熱の 一部が梁に吸収されたためと思われる。スラブ厚 $150 \mathrm{~mm}$ の試験体に ついては試験体 1 の結果のみを示したが、温度測定位置における各 試験体のばらつきは少なく、同様の結果となっていた。

次に、裏面温度の初期值からの温度上昇（温度測定值(1)）を図 11

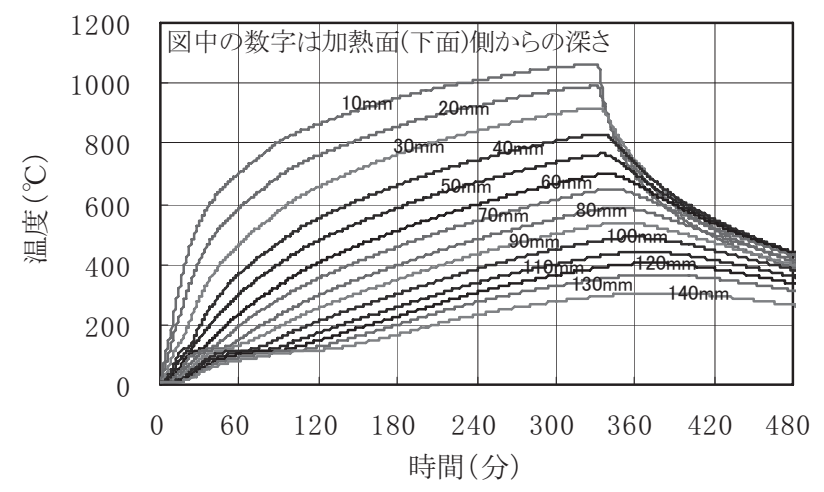

図 5 コンクリート温度(試験体 1 スラブ厚 $150 \mathrm{~mm}$ : 温度測定位置(1)

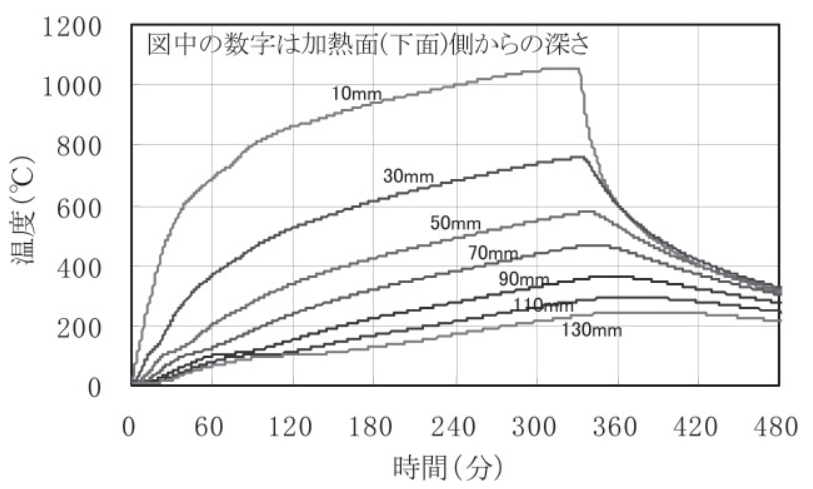

図 6 コンクリート温度(試験体 1 スラブ厚 $150 \mathrm{~mm}$ : 温度測定位置(2) 


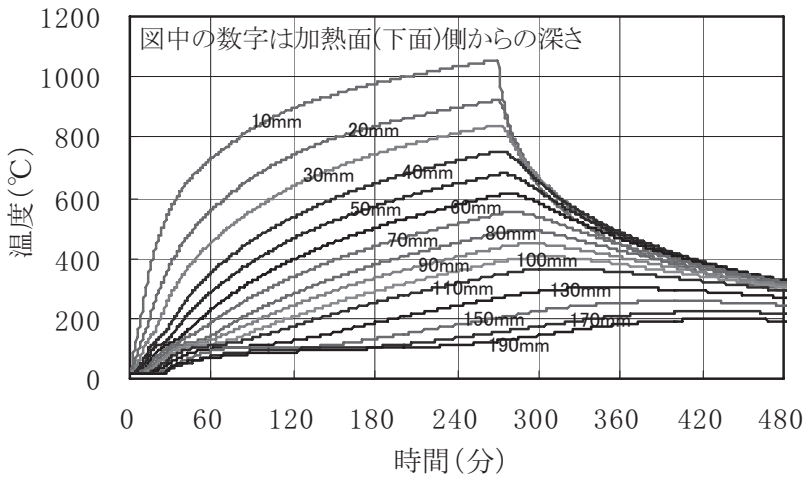

図 7 コンクリート温度(試験体 3 スラブ厚 $200 \mathrm{~mm}$ : 温度測定位置(1)

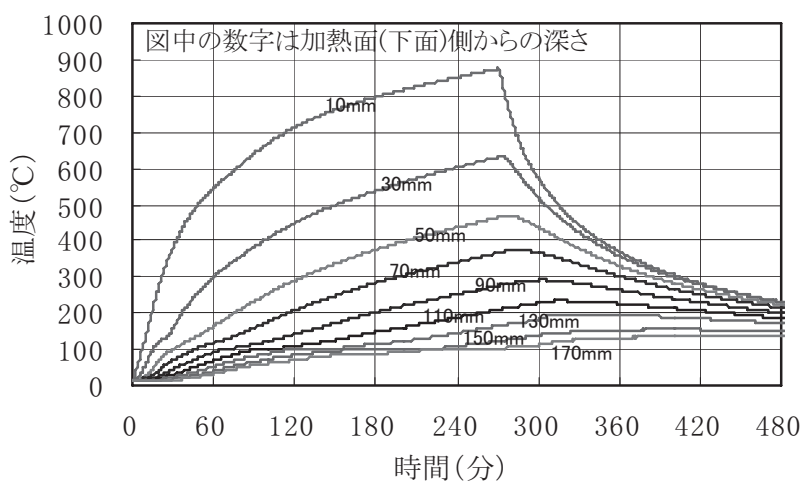

図 8 コンクリート温度(試験体 3 スラブ厚 $200 \mathrm{~mm}$ 温度測定位置(2)

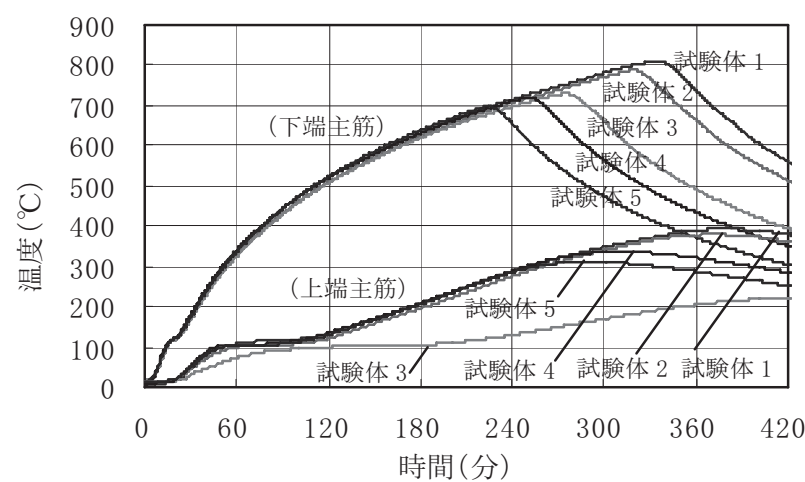

図 9 主筋温度 (温度測定位置(1)

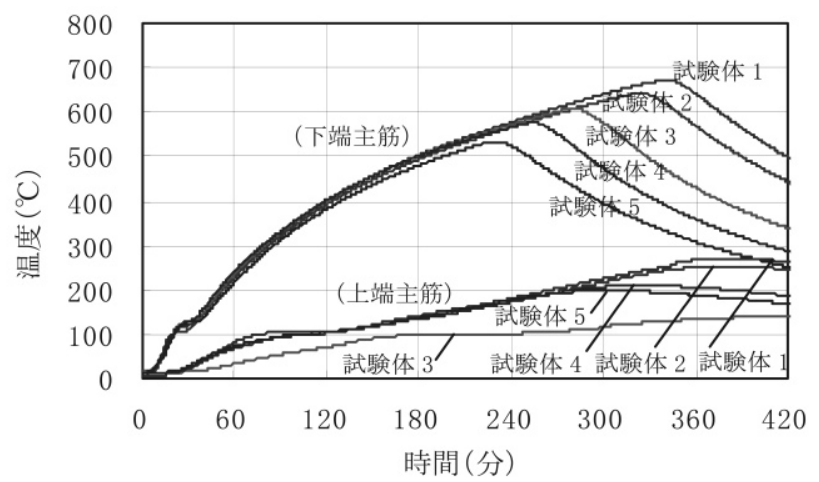

図 10 主筋温度(温度測定位置(2)

に示す。参考として、R C スラブの裏面温度上昇が平成 12 年建設省 告示第 1432 号で許容値として用いられている 140K に到達したとき の時間を表 6 に示す。スラブ厚を $150 \mathrm{~mm}$ にした試験体（試験体 $1,2,4,5)$ はいずれも 200 分前後で許容值に到達している。スラブ厚
を $200 \mathrm{~mm}$ にした試験体 3 は加熱中に許容值には到達しなかったが、 加熱終了後も温度が上昇し、361 分で許容值に到達している。

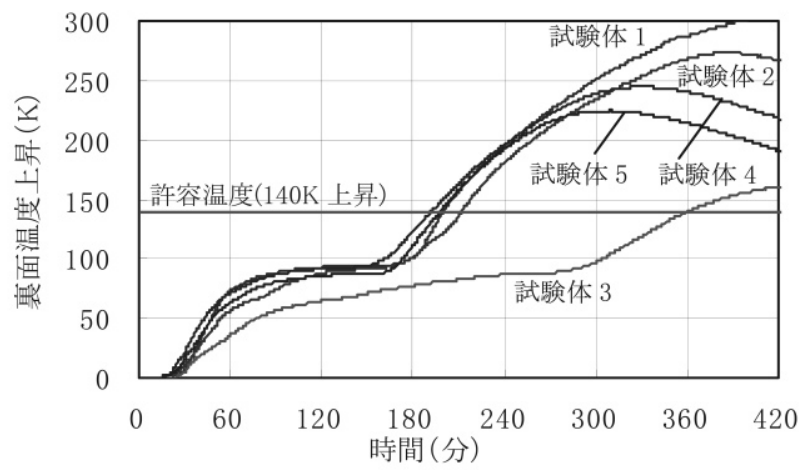

図 11 裏面温度上昇

表 6 裏面温度許容值到達時間

\begin{tabular}{|c|c|c|}
\hline 試験体名 & スラブ厚 & 許容值到達時間 \\
\hline 試験体 1 & $150 \mathrm{~mm}$ & 200 分 \\
\hline 試験体 2 & $150 \mathrm{~mm}$ & 212 分 \\
\hline 試験体 3 & $200 \mathrm{~mm}$ & 361 分 $* 1$ \\
\hline 試験体 4 & $150 \mathrm{~mm}$ & 193 分 \\
\hline 試験体 5 & $150 \mathrm{~mm}$ & 198 分 \\
\hline
\end{tabular}

※1 270 分で加熱終了した後の温度上昇で許容值に到達

\section{4.2 変形測定結果}

両端の支持点に対する試験体中央部の鉛直方向変位（上向きの変 位を正とする）を図 12 に、実験結果一覧を表 7 に示す。

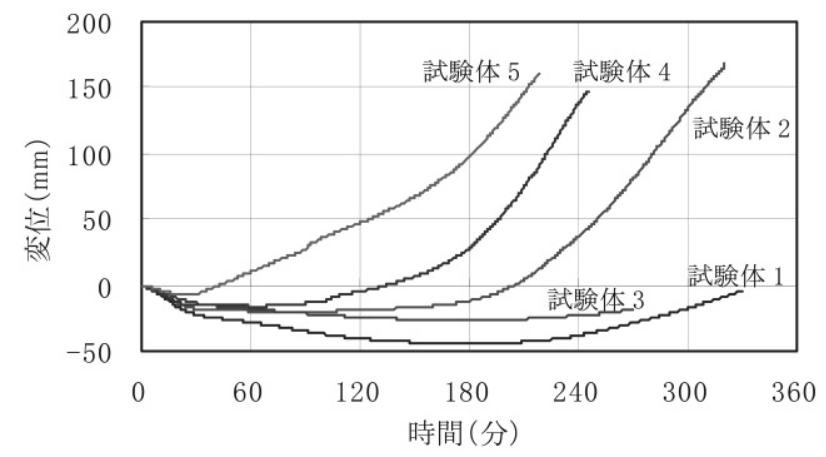

図 12 試験体中央部の鉛直変位

本稿では、荷重を保持出来なくなった状態を「破壞」と定義する。 前に述べたように、試験体 1～3 は加熱を終了するまで荷重を保持し たため、加熱終了後載荷荷重を増加させて試験体を破壞した。図 12 は加熱開始から加熱を終了するまでの変位を示す。加熱後破壊実験 の結果は表 7 に示寸。また表 7 には各到達時間（加熱終了時、破壞 時、試験体中央部の下向き変位最大時及び $0 \mathrm{~mm}$ 到達時)、試験体中央 部の変位（下向き最大值、加熱終了時、破壊時）及び載荷荷重とし て梁縁位置における曲げモーメントの值を併せて示す。試験体中央 部はいずれの試験体も加熱初期に下向きの変形を生じるが、加熱が 進むにつれ下向きの変形は緩やかになり途中から上向きの変形に反 転している。反転後は比較的緩やかに変形が進展し、試験体 4、試験 体 5 については変位が $150 \mathrm{~mm}$ 前後に達したところで破壊した。破壊 による変形の急増は特に見られず、緩やかに荷重が抜けて荷重支持 能力を喪失した。試験体 2 は $150 \mathrm{~mm}$ を越える大変形を生じたが破壊 
表 7 実験結果の一覧

\begin{tabular}{|c|c|c|c|c|c|c|c|c|c|c|c|}
\hline \multirow{3}{*}{ 試験体名 } & \multicolumn{4}{|c|}{ 時間 (分) } & \multicolumn{3}{|c|}{ 試験体中央部変位 (mm) } & \multicolumn{4}{|c|}{ 載荷荷重 } \\
\hline & \multirow[b]{2}{*}{$\begin{array}{l}\text { 加熱 } \\
\text { 終了 }\end{array}$} & \multirow{2}{*}{ 破壞 } & \multirow{2}{*}{$\begin{array}{l}\text { 下向き変位 } \\
\text { ピーク時 }\end{array}$} & \multirow{2}{*}{$\begin{array}{l}\text { Omm } \\
\text { 到達時 }\end{array}$} & \multirow{2}{*}{$\begin{array}{l}\text { 下向き変位 } \\
\text { の最大值 }\end{array}$} & \multirow[b]{2}{*}{ 加熱終了時 } & \multirow[b]{2}{*}{ 破壊時※1 } & \multicolumn{2}{|c|}{ 載荷加熱時 } & \multicolumn{2}{|c|}{ 加熱後破壊時※2 } \\
\hline & & & & & & & & $(\mathrm{kN} \cdot \mathrm{m})$ & $\begin{array}{l}\text { 荷重比 } \\
\mathrm{M} / \mathrm{Mu}\end{array}$ & $(\mathrm{kN} \cdot \mathrm{m})$ & $\begin{array}{l}\text { 荷重比 } \\
\mathrm{M} / \mathrm{Mu}\end{array}$ \\
\hline 試験体1 & 332 & - & 184 & - & -43.8 & -2.9 & (134.2) & 10.8 & 0.45 & 23.9 & 0.99 \\
\hline 試験体2 & 315 & - & 74 & 204 & -20.3 & 157.6 & $(167.8)$ & 20.9 & 0.87 & 22.1 & 0.92 \\
\hline 試験体3 & 270 & - & 169 & - & -25.7 & -18.2 & $(171.6)$ & 30.2 & 0.87 & 46.5 & 1.32 \\
\hline 試験体4 & 245 & 245 & 67 & 134 & -15.9 & \multicolumn{2}{|c|}{147.7} & 37.6 & 0.87 & - & - \\
\hline 試験体5 & 218 & 218 & 26 & 43 & -7.3 & \multicolumn{2}{|c|}{160.9} & 42.8 & 0.99 & - & - \\
\hline
\end{tabular}

※1（）は加熱中に破壞せず、加熱後破壞実験を行った試験体の破壊時変位を表す $※ 2$ 加熱終了後に荷重を増加させて破壊した時の荷重

には至らなかった。試験体 1 は 332 分、試験体 3 は 270 分まで加熱 を続けたが、破壞に至らず変位も $0 \mathrm{~mm}$ を下回っていた。

いずれの試験体も 3 時間を超える長時間の加熱に対して荷重を保 持することができている。特に、試験体 $2 \sim 5$ は構造設計上の最大荷 重（荷重比 0.66）を上回る高い荷重に対して荷重支持能力を保持し ており、RCスラブは負曲げモーメントに対して極めて高い耐火性 能を有していることが明らかになった。

\section{4 .3 載荷加熱実験に対する考察}

試験体中央部の加熱初期における下向きの変形は、断面内におけ る加熱面側と非加熱面側の温度差により生じたものと思われる。加 熱が進み、下端主筋の剛性が低下寸るにつれ下端主筋の熱膨張力は 小さくなり、上端主筋に生じる引張力を下回ることで変形が上向き に転じたものと推察される。

実験パラメーターに設定した荷重比、配筋、スラブ厚の影響につ いて所見を述べる。荷重比の影響を見るためスラブ厚と配筋を同じ とし荷重比を変えた試験体 1 と試験体 2 及び試験体 4 と試験体 5 を 比較する。変形の進展は荷重比が大きい試験体ほど早い。一方、下 向きの最大変形量は、荷重比が大きい試験体ほど小さくなる傾向が 見られた。

配筋の影響を見るためスラブ厚、荷重比及び下端主筋配筋を同じ とし、上端主筋の配筋を変えた試験体 2 と試験体 4 を比較すると、 上端主筋量の多い試験体 4 の方が変形の進展が早い。いずれの試験 体も (1) 式に従い常温時に上端主筋に生じる引張応力度が等しくな るよう載荷荷重を設定しているため、上端主筋に対する条件は等し い。一方、作用曲げモーメントについては上端主筋量が多い試験体 4 の方が大きくなるため、下側コンクリートの負担圧縮力が大きくな り、コンクリートの劣化が早く生じたものと思われる。

スラブ厚の影響を見るため主筋配筋と荷重比を同じとし、スラブ 厚を変えた試験体 2 と試験体 3 を比較すると、スラブ厚が大きい試 験体 3 の方が変形の進展が緩やかである。試験体 2 に比べ試験体 3 は作用曲げモーメントが大きいため、下側コンクリートの負担圧縮 力が大きくなる。一方、スラブ厚が大きくなることで圧縮力を負担 するコンクリートの厚みが増えるため、熱劣化の影響は緩和される。 後者の影響が勝るため、変形性能が向上したものと思われる。

\section{4.4 加熱後破壊実験に対する考察}

加熱後破壊実験を行った試験体 1～3の結果について所見を述べる。 試験体 1 は 332 分の加熱で破壊に至らなかったため、加熱終了後載 荷荷重を増加させたところ、載荷荷重が荷重比で 0.99 に達したとこ ろで破壊に至った。試験体 2 は 315 分の加熱で変位が $157 \mathrm{~mm}$ まで達 したが破壊しなかったため、加熱を終了し、載荷荷重を増加させた
ところ、変位を約 $10 \mathrm{~mm}$ 、載荷荷重を荷重比で 0.87 から 0.92 に僅か に増加させたところでそれ以上荷重が上がらなくなり破壊した。試 験体 2 は加熱中に破壞に至らなかったが、加熱終了時にほぼ破壊状 態にあったものと推察される。試験体 3 は 270 分で加熱を終了した 後、載荷荷重を増加させたところ荷重比で 1.32 に達したところで破 壊に至った。スラブ厚 $150 \mathrm{~mm}$ の試験体 1 と試験体 2 は(1) 式で求まる 常温時の終局曲げ耐力を若干下回る荷重で破壊に至っているが、ス ラブ厚 $200 \mathrm{~mm}$ の試験体 3 は、破壊時荷重が (1) 式で求まる常温時の終 局曲げ耐力を大きく上回っている。この理由として、塑性変形後の ひずみ硬化による上端主筋の強度上昇が考えられる。また、2.4.5 に後述するヒンジ発生位置が影響した可能性も考えられる。

\section{4.5 試験体の破壊状況}

試験体の破壊状況を写真 1 に示す。ヒンジ位置が材端部 (梁縁位置) から少し外れたところに形成されていることがわかる。ヒンジが形成された 位置は試験体により異なるが、加熱により大変形に達した試験体 2、試験
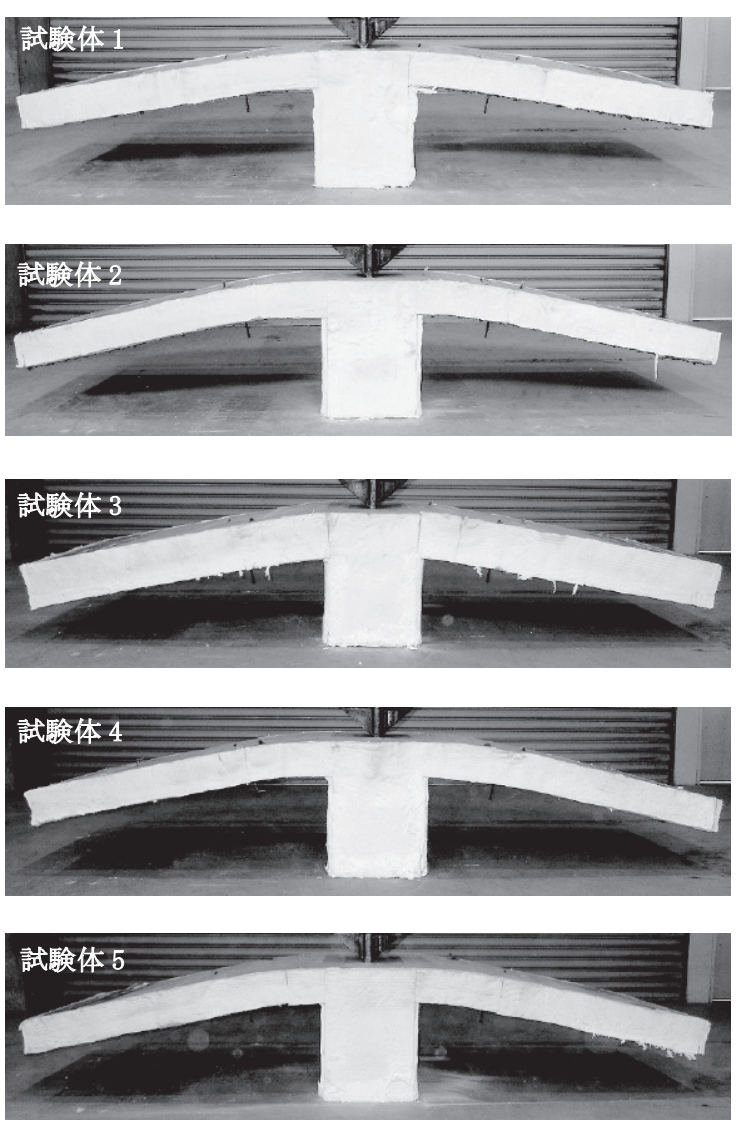

写真 1 試験体の破壊状況 
体 4 、試験体 5 はヒンジ位置がより外側に形成されている。ヒンジ位置が材 端部より外側に形成された理由として、図 5〜8 のコンクリート温度が示す ように支持梁の影響で加熱部に比べ材端部付近のスラブ温度が若干低く なったことが考えられる。ヒンジ位置がずれたことでせん断スパンが短くな り、破壊位置における荷重比は、表 1 に示寸值よりも小さくなっている可能 性がある。実験試験体の耐火性能を評価する際には、この点を考慮する 必要があるものと思われる。スラブ上面の一例として試験体 2 と試験体 3 の破壊状況を写真 2 に示寸。写真中の試験体番号は、この論文の試験 体番号とは一致していない。ひび割れ位置は梁縁位置から若干外側に 形成されており、他の試験体でも同様の傾向が見られた。試験体下面に ついては、顕著なひび割れ、圧壊等の破壊現象は特に見られなかった。
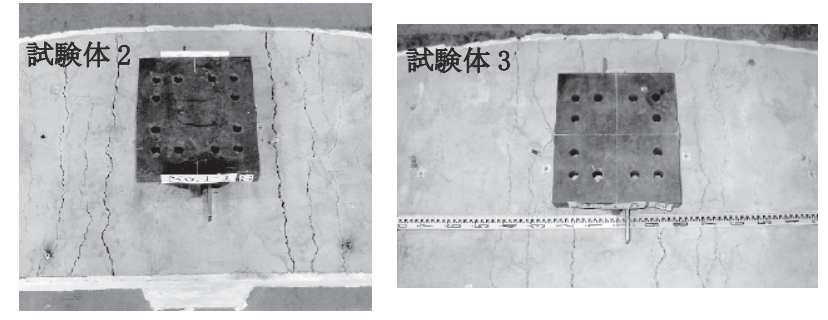

写真 2 試験体の破壊状況(上面の亀裂状況)

\section{3. 数值解析}

\section{1 解析の目的}

荷重比、主筋配筋及びスラブ厚は負曲げモーメントを受ける R C スラブの耐火性能に大きく影響することが実験により示された。本 節では各因子の影響を定量的に把握し、負曲げモーメントを受ける R C スラブが破壊に至る挙動を詳細に検討するため、数值解析によ る検討を行った。3.3 節で実験との比較検討を行い、解析手法の妥当 性を確認した上で、3.4 節で解析により得られた内部応力度の推移か ら破壊に至る挙動について考察した。3.5 節では、荷重比、主筋配筋、 スラブ厚によるパラメータースタディを行い、これらの因子が火災 時の変形挙動と火災時耐力に与える影響について検討した。

\section{2 解析手法及び解析モデル}

材料の非線形性を考慮した熱弾塑性解析手法を用いて数值解析を 行った。解析手法には文献 1 で正曲げモーメントを受けるR C スラ ブの解析に用いた方法を採用した。解析手法の概要は文献 7)，8）に 示されている。2 章に示寸載荷加熱実験を図 13 でモデル化した。中 央の支持梁は加熱を受けても強度、剛性とも保持されるものと仮定 して梁部分を除き、加力点の両側に長さ $1200 \mathrm{~mm}$ の R C 片持ちスラブ が接合するモデルとした。 R C スラブの材軸方向を 16 の小部材に要 素分割し、さらにその断面を図 14 に示寸メッシュ状のスライス断面 でモデル化した。スライス内の温度は微少時間内では均一と仮定し た。図 14 の黒色に塗りつぶした部分は鉄筋を表す。鉄筋はD13 と断 面積が等価な角形断面 $\left(1.27 \mathrm{~cm}^{2}\right)$ とし、鉄筋芯が試験体と同じ位置 （スラブ端から $37 \mathrm{~mm}$ ) となるようにモデル化した。断面内の温度分 布には実験結果を用いた。高さ $10 \mathrm{~mm}$ 間隔で測定した結果を直線補間 して、断面内部の温度分布を設定した。なお、2 章で示したように実 験試験体は、スラブ端部より僅かに外れたところでヒンジが形成さ れており、ヒンジ位置のコンクリート内部温度は、図 2 に示寸温度 測定位置(2)よりも温度測定位置(1)に近いものと思われる。解析を単 純化する意味も含めスラブの内部温度分布には測定位置(1)におる

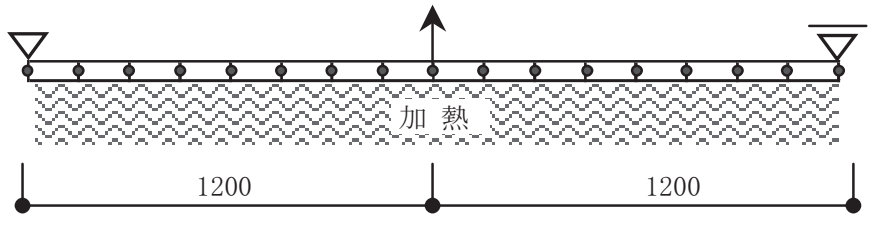

図 13 解析モデル

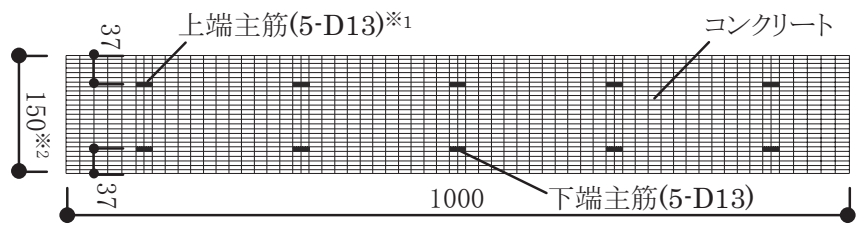

※1 試験体 4、5 は 9-D13 ※2 試験体 3 は $200 \mathrm{~mm}$

図 14 材軸方向に分割した各要素のスライス断面

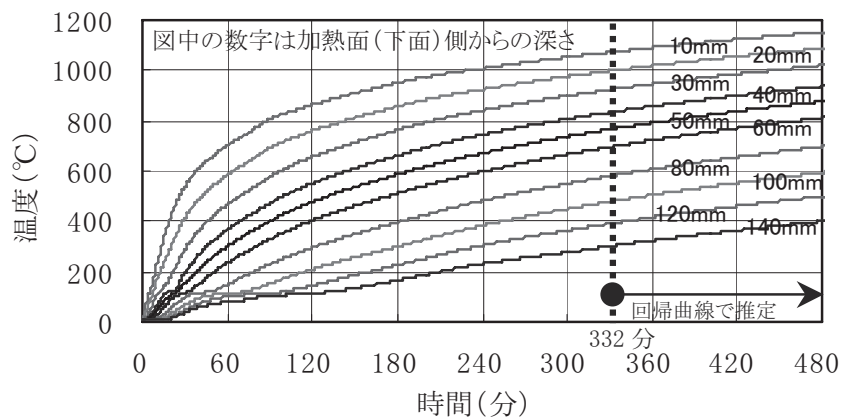

図 15 解析用コンクリート内部温度モデル (スラブ厚 150mm)

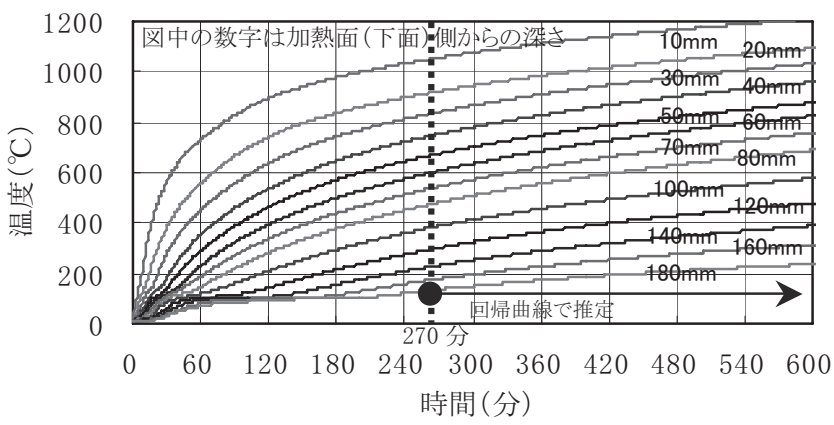

図 16 解析用コンクリート内部温度モデル (スラブ厚 200mm)

温度を採用し、スラブ厚 $150 \mathrm{~mm}$ については図 5、スラブ厚 $200 \mathrm{~mm}$ につ いては図 7 の測定結果を用いた。試験体 1 （スラブ厚 $150 \mathrm{~mm}$ ）は 332 分、試験体 3 （スラブ厚 $200 \mathrm{~mm}$ ）は 270 分で加熱を終了したため、上 記加熱時間を超える範囲については、加熱中の測定温度を対数関数 で回帰した近似曲線により、コンクリート内部温度を推定した。解

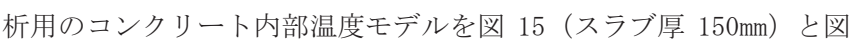
16 （スラブ厚 $200 \mathrm{~mm}$ ）に示す。本解析では、コンクリート要素に過渡 ひずみを考慮し、Anderberg らのモデル $(\mathrm{k}=2.35)^{9)}$ を採用した。主 筋の応力ーひずみ関係については、主筋（SD295A）の高温引張試験結 果から作成した文献 1 に示すモデルを採用した。コンクリートと主 筋の線膨張係数及びコンクリートの応力ーひずみ関係については Eurocode ${ }^{10)}$ に示された関係式を用いた。

\section{3 解析結果}

試験体 1〜 5 に対する解析結果と実験結果の比較を図 17〜図 21 に 示寸。図中のム印は解析の破壊時を示寸。解析值は実験值と全体的 な挙動に関して概ね一致している。加熱の途中から解析は実験に比 べ変形が早く進展する傾向が見られた。また、解析は実験に比べ早 
期に破壊に至っており耐火性能を低めに評価する傾向が見られた。 この理由として実験試験体は、ヒンジ位置が梁縁位置から少し外れ たところに形成されたことで、せん断スパンが若干短くなっていた

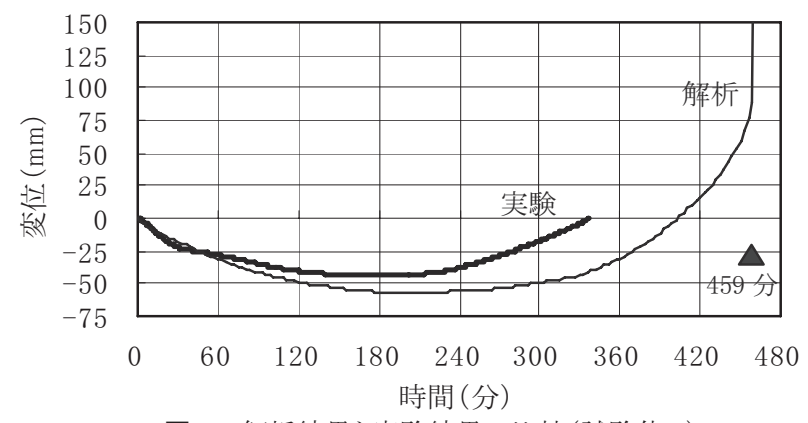

図 17 解析結果と実験結果の比較(試験体 1)

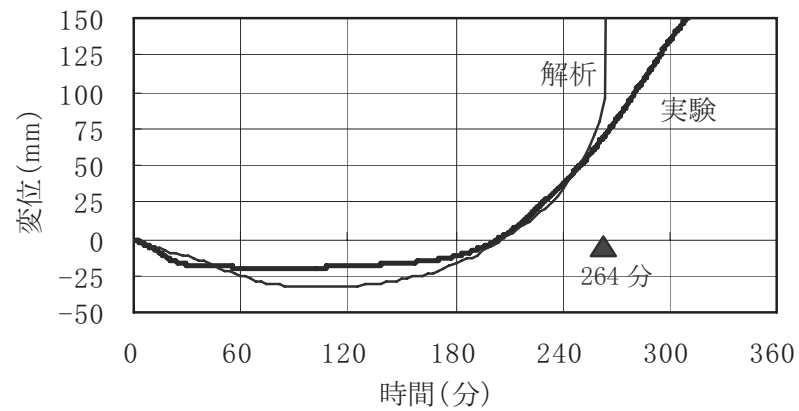

図 18 解析結果と実験結果の比較 (試験体 2)

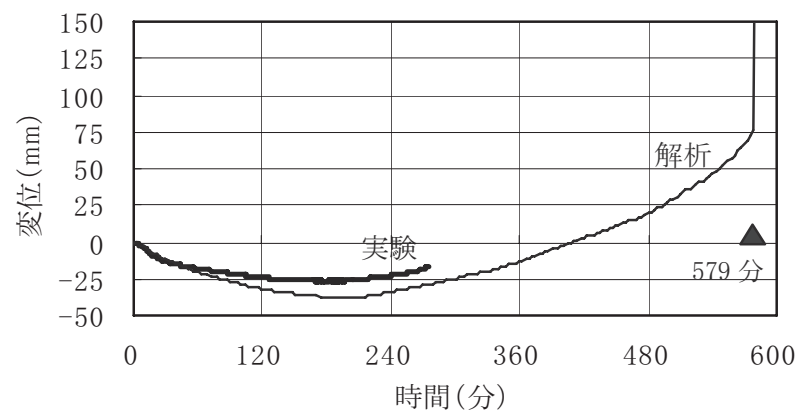

図 19 解析結果と実験結果の比較(試験体 3)

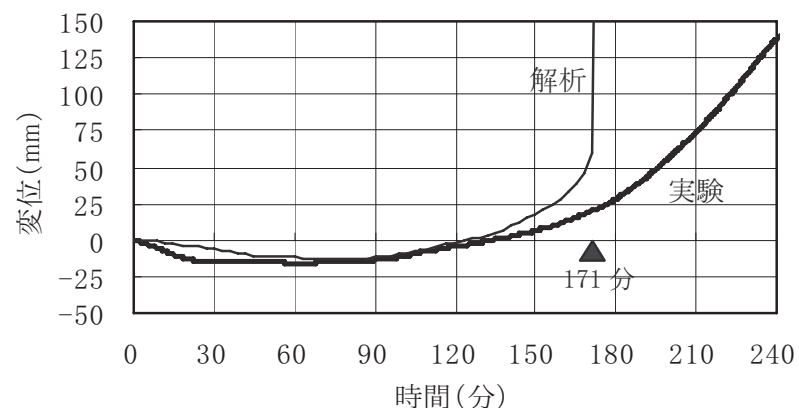

図 20 解析結果と実験結果の比較 (試験体 4)

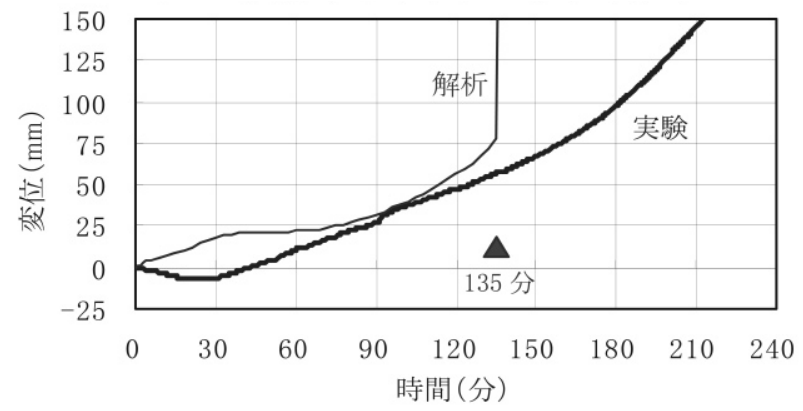

図 21 解析結果と実験結果の比較(試験体 5)

\section{ことが可能性として考えられる。}

\section{4 破壊挙動の考察}

解析で得られた内部応力度分布の推移から負曲げモーメントを受 ける R C スラブが加熱によって破壊に至る挙動について検討する。 ここでは、荷重比を同じとし主筋配筋とスラブ厚を変化させた試験 体 2、試験体 3、試験体 4 の結果から考察を行う。各試験体の内部応 力度分布の推移を図 22〜24 に示寸。下側コンクリートの圧縮応力度 の推移に着目し、コンクリートの圧縮応力度を拡大表示する。主筋 の応力度は図中に数值で示す。また、応力中心間距離 $\mathrm{j}$ の值を図中 に示す。いずれの試験体も下面からの加熱によりコンクリート強度 が低下することで、圧縮側コンクリートの応力度分布は、逆くの字 形の山型分布を形成する。加熱の経過に伴い山形分布は徐々に上側 に移動する。これに伴い応力中心間距離が短くなり、上端主筋とコ ンクリートに生じる応力度が徐々に大きくなる。そして、上端主筋 に生じる引張応力度が強度に達したところで破壊に至っている。破 壊時の主筋応力度は常温の降伏強度である $372 \mathrm{~N} / \mathrm{mm}^{2}$ を上回っている がこれは、塑性変形後のひずみ硬化によるものである。今回の解析

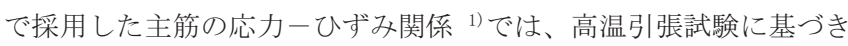
塑性変形後のひずみ硬化を考慮したモデルとしている。

上端主筋の配筋を変えた試験体 2 と試験体 4 を比較すると、試験 体 4 は試験体 2 に比ベコンクリートに生じる圧縮応力度が大きいた め、山型分布が上側へ移動することによる上端主筋の引張応力度の 上昇が早まり、試験体 2 に比べ 90 分程早く強度に達して破壊してい る。引張鉄筋比が釣合い鉄筋比以下の場合、常温の設計では (1) 式等 に従い主筋に生じる引張応力度の大きさで構造性能を評価すること が一般的であるが、火災時はコンクリートに生じる圧縮応力度の大 きさが耐火性能に大きく影響するため、火災時の設計では、主筋に 生じる引張応力度だけでなく、コンクリートに生じる圧縮応力度の 大きさも適切に考慮する必要があるといえる。

スラブ厚を変えた試験体 2 と試験体 3 を比較すると、コンクリー 卜に生じる圧縮応力度の最大值はほぼ同じである。また、圧縮応力 度の山形分布が上側に移動する速度についても大きな違いは見られ ない。しかし、スラブ厚が大きくなることで、山形分布が上側に移 動することによる主筋の引張応力度の上昇が緩やかになっているこ とがわかる。応力中心間距離に着目すると、試験体 2 は常温時から $32 \mathrm{~mm}$ 短くなったところで破壊しているのに対し、試験体 3 は $58 \mathrm{~mm}$ 短くなったところで破壊している。スラブ厚が大きくなるとそれに 比例して山形分布が破壊位置に移動するまでの距離も長くなるが、 山形分布が上側に移動する速度はあまり変わらないため、破壊まで に要する加熱時間は長くなる。このため、主筋配筋と荷重比が同じ 場合は、スラブ厚が大きくなるほど耐火時間は長くなる。なお、ス ラブ厚が $200 \mathrm{~mm}$ までの範囲においてはこの傾向が実験でも確認され ているが、スラブ厚がさらに大きくなるとコンクリートの圧壊等で 破壊が早期に生じる可能性もあり、この傾向が必ずしも得られると は言い切れない。この点については実験等による検証が必要であり、 今後の課題としたい。

次に上端主筋に着目すると、いずれの試験体も破壊時に高い強度 を保持しており、加熱による強度低下を生じていない。図 9 に示す ように上端主筋の温度上昇は緩やかであり、上端主筋の強度低下が 負曲げ耐力に与える影響は極めて小さいことを確認した。 

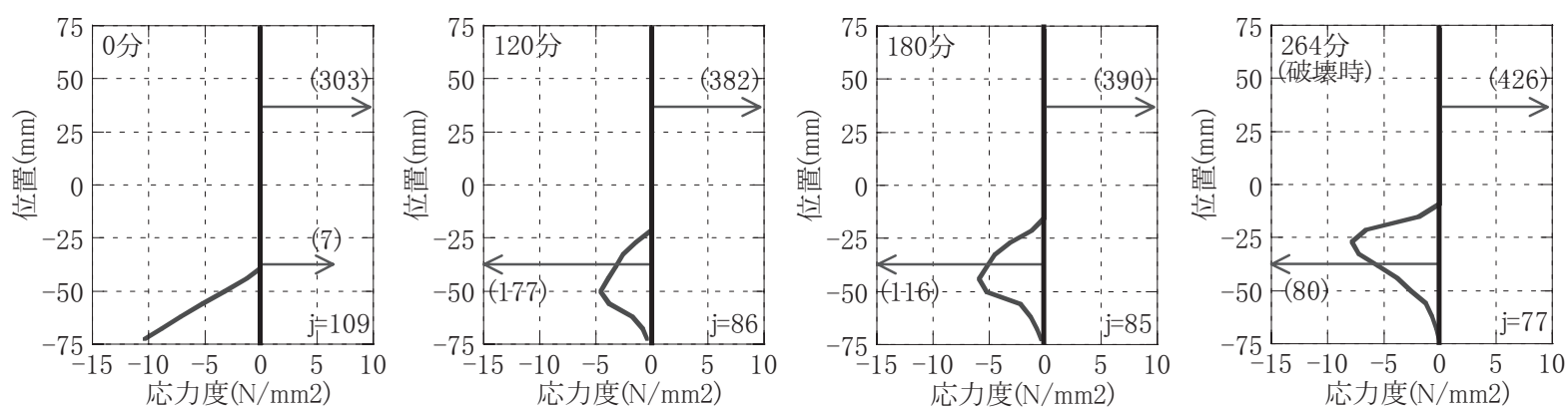

•( )は主筋の

応力度を表す

単位: $\mathrm{N} / \mathrm{mm}^{2}$

jは応力中心間

距離を表す

単位: $m m$

図 22 応力度分布の経時変化 (試験体 2)
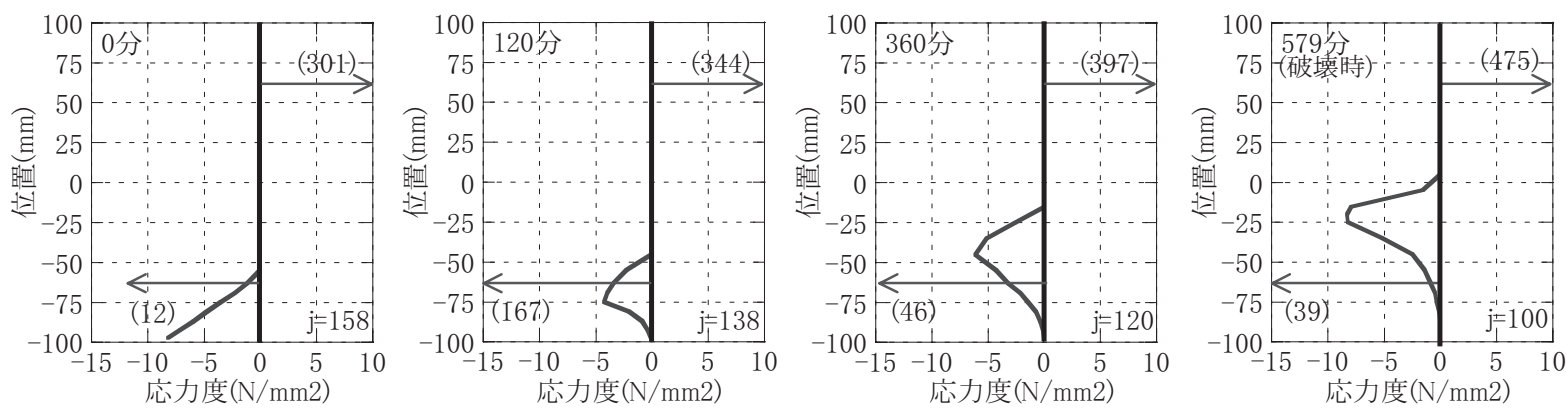

•( ) は主筋の

応力度を表す 単位: $\mathrm{N} / \mathrm{mm}^{2}$

• j は応力中心間 距離を表す

単位: $m m$

図 23 応力度分布の経時変化 (試験体 3 )
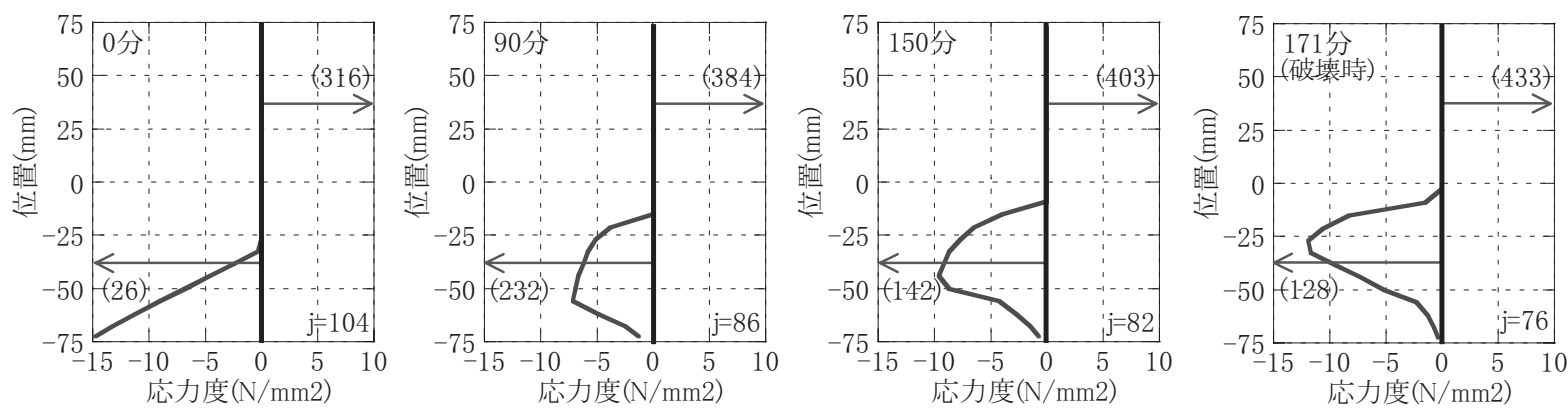

・( )は主筋の 応力度を表す 単位: $\mathrm{N} / \mathrm{mm}^{2}$

・ $\mathrm{j}$ は忘力中心間 距離を表す

単位: $m m$

図 24 応力度分布の経時変化 (試験体 4)

3. 5 パラメータースタディ

荷重比、主筋配筋、スラブ厚が火災時の変形挙動及び火災時耐力 に与える影響を定量的に把握するため、パラメータースタディを行 つた。解析ケースを表 8 に示す。

表 8 解析パラメーター

\begin{tabular}{|c|c|c|c|c|c|c|}
\hline シリーズ & No. & $\begin{array}{c}\text { スラブ厚 } \\
(\mathrm{mm})\end{array}$ & 上端筋 & 下端筋 & $\begin{array}{l}\text { 荷重比 } \\
\mathrm{M} / \mathrm{Mu}\end{array}$ & 備考 \\
\hline \multirow{3}{*}{1} & $1-1$ & \multirow{3}{*}{150} & \multirow{3}{*}{ D13@200 } & \multirow{3}{*}{ D13@200 } & 0.45 & 試験体1 \\
\hline & $1-2$ & & & & 0.68 & \\
\hline & $1-3$ & & & & 0.87 & 試験体2 \\
\hline \multirow{3}{*}{2} & $2-1$ & \multirow{3}{*}{150} & \multirow{3}{*}{ D13@100 } & \multirow{3}{*}{ D13@200 } & 0.45 & \\
\hline & $2-2$ & & & & 0.68 & \\
\hline & $2-3$ & & & & 0.87 & 試験体4 \\
\hline \multirow{3}{*}{3} & $3-1$ & \multirow{3}{*}{200} & \multirow{3}{*}{ D13@200 } & \multirow{3}{*}{ D13@200 } & 0.45 & \\
\hline & $3-2$ & & & & 0.68 & \\
\hline & $3-3$ & & & & 0.87 & 試験体3 \\
\hline \multirow{3}{*}{4} & $4-1$ & \multirow{3}{*}{150} & \multirow{3}{*}{ D13@200 } & \multirow{3}{*}{-} & 0.45 & \\
\hline & $4-2$ & & & & 0.68 & \\
\hline & $4-3$ & & & & 0.87 & \\
\hline
\end{tabular}

スラブ厚 $150 \mathrm{~mm} 、$ 上下端主筋 D13@200 のシリーズ 1 を標準とし、 これと異なるパラメーターをハッチで表示する。シリーズ 2 は上端 主筋をD13@100、シリーズ 3 はスラブ厚を $200 \mathrm{~mm}$ にしている。なお、 試験体 1 はNo. 1-1 に、試験体 2 はNo. 1-3 に、試験体 3 はNo. 3-3 に、
試験体 4 は No. 2-3 に相当する。シリーズ 4 は圧縮側主筋の影響を検 討するため下端側主筋を省略している。解析結果を図 25 2 28 に示す。

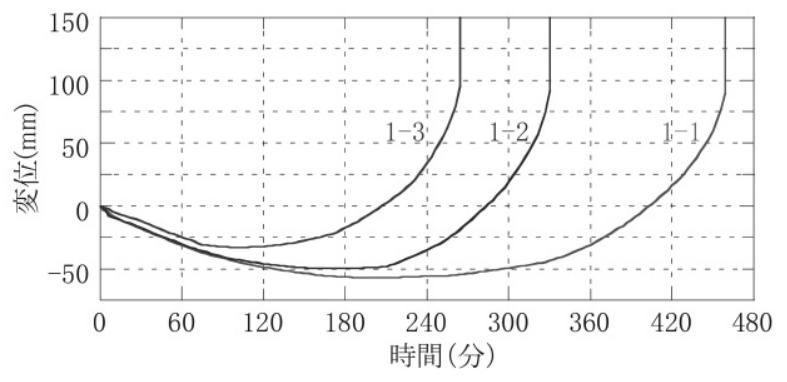

図 25 解析結果 (パラメータースタディシリーズ 1)

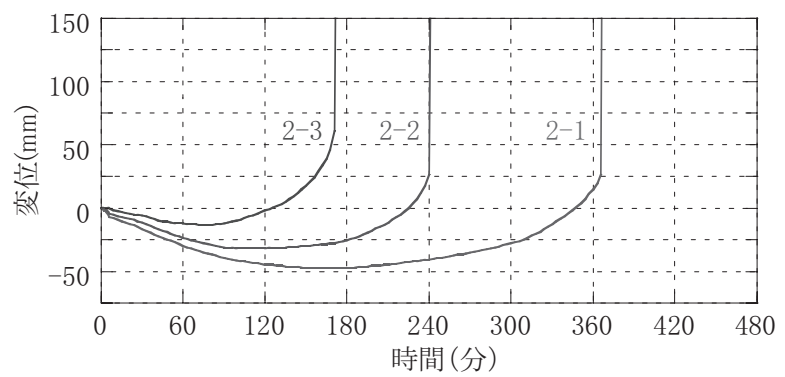

図 26 解析結果(パラメータースタディ シリーズ 2) 


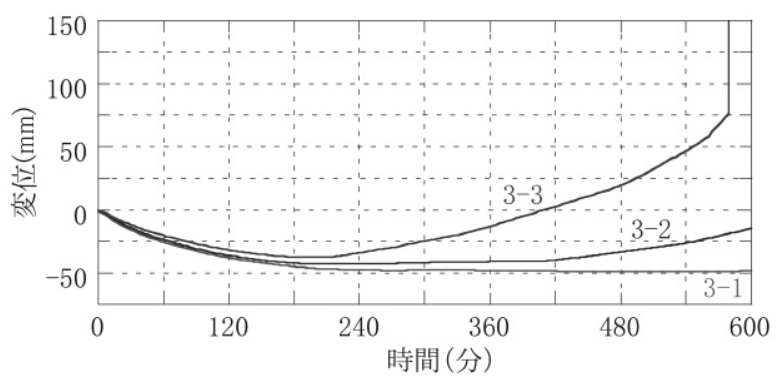

図 27 解析結果 (パラメータースタディ シリーズ 3)

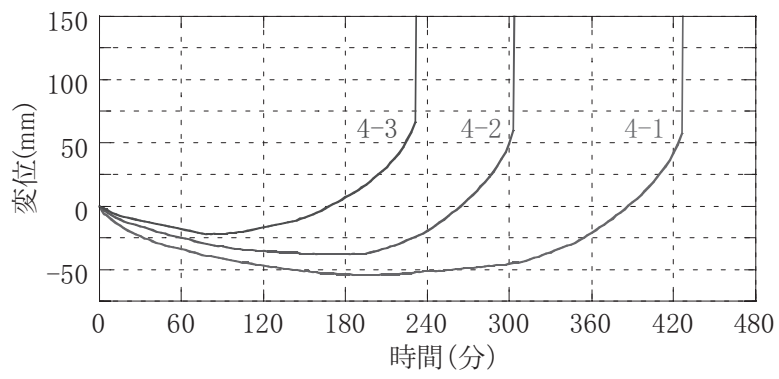

図 28 解析結果 (パラメータースタディ シリーズ 4)

表 9 荷重比と耐火時間の関係

\begin{tabular}{|c|c|c|c|c|}
\hline \multirow{2}{*}{$\begin{array}{c}\text { 荷重比 } \\
\mathrm{M} / \mathrm{Mu}\end{array}$} & \multicolumn{4}{|c|}{ 耐火時間(分) } \\
\cline { 2 - 5 } & シリーズ1 & シリーズ2 & シリーズ3※1 & シリーズ4 \\
\hline 0.45 & 459 & 366 & - & 426 \\
\hline 0.68 & 330 & 240 & - & 303 \\
\hline 0.87 & 264 & 171 & 579 & 231 \\
\hline
\end{tabular}

※1 M/Mu=0.45及び0.68は600分の加熱で破壊せず

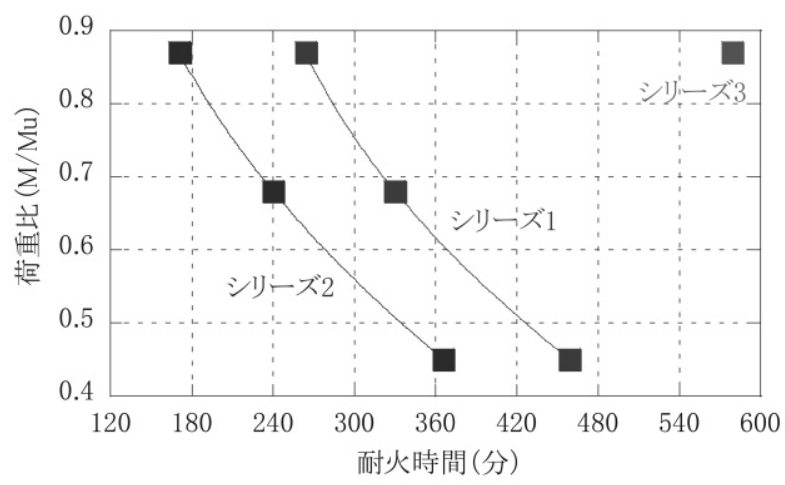

図 29 荷重比と耐火時間の関係 (1)

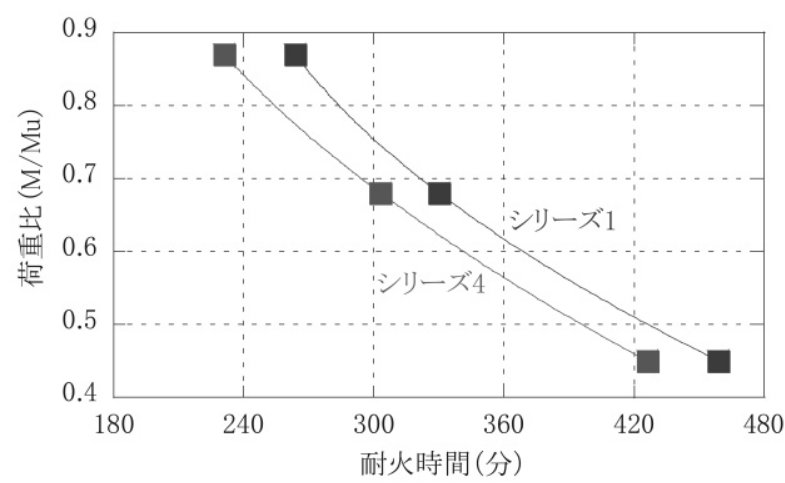

図 30 荷重比と耐火時間の関係 (2)

解析では最大 600 分まで加熱を与えた。シリーズ 3 で荷重比を 0.45 及び 0.68 としたモデルについては、600 分の加熱で破壊に至らなか ったため、600 分までの結果を示す。加熱により試験体が破壊した時
間（耐火時間）と荷重比（M/Mu）の関係を表 9 及び図 29、図 30 に示 す。図 29 はシリーズ 1、2、3 の比較を、図 30 はシリーズ 1 とシリ 一ズ 4 の比較を示す。荷重比が大きくなると耐火時間は短くなる関 係にあり、若干下側に凸となる曲線を描いている。参考までに両者 の関係を 2 次の多項式で回帰した結果を図中に示す。近似式は以下 の式で表される。

$\mathrm{M} / \mathrm{M}_{\mathrm{u}}=\mathrm{A}+\mathrm{B} \times \mathrm{t}+\mathrm{C} \times \mathrm{t}^{2}$

(2) 式

ここに、 $\mathrm{M} / \mathrm{M}_{\mathrm{u}}$ : 荷重比

M : 作用曲げモーメント

$M_{u} \quad$ : (1) 式で求まる常温時の終局曲げ而力

$\mathrm{t}$ : 耐火時間（分）

A, B, C：係数（表 10 に示す）

表 10 回帰式の係数

\begin{tabular}{|c|c|c|c|}
\hline & シリーズ 1 & シリーズ 2 & シリーズ 4 \\
\hline 係数 A & 2.120 & 1.536 & 1.756 \\
\hline 係数 B & $-6.217 \times 10^{-3}$ & $-4.710 \times 10^{-3}$ & $-4.745 \times 10^{-3}$ \\
\hline 係数 C & $5.620 \times 10^{-6}$ & $4.760 \times 10^{-6}$ & $3.943 \times 10^{-6}$ \\
\hline
\end{tabular}

この近似式でシリーズ 1, 2, 4 の火災時耐力（破壊時の作用曲げモ 一メント）を概ね予測することが可能である。実験との比較で述心゙ たように、解析は実験に比べ耐火性能を低めに評価する傾向があり、 (2)式で求まる耐力は、実際よりも低めの值を取るものと思われる。

シリーズ 1,2,3 を比較した結果（図 29）を見ると、上端主筋を D13@100 としたシリーズ 2 は、D13@200 としたシリーズ 1 に比べ同じ 荷重比に対して 90 分程度耐火時間が短くなっている。一方、スラブ 厚を $200 \mathrm{~mm}$ にしたシリーズ 3 は、破壊に至ったのが荷重比を 0.87 と した 1 ケースのみであるが、この 1 ケースについて比較すると、ス ラブ厚が $150 \mathrm{~mm}$ のシリーズ 1 に比べ耐火時間が 315 分長くなってい る。下端主筋（圧縮側主筋）を有するシリーズ 1 は、下端主筋を省 略したシリーズ 4 に比べ、同じ荷重比に対して耐火時間が 30 分程長 くなっている(図 30)。この理由として、下端主筋を有するシリーズ 1 は下端主筋が圧縮力の一部を負担することで、下端主筋の無いシリ 一ズ 4 に比心゙応力中心間距離が長くなったためと考えられる。しか し、加熱による強度低下で破壊時における下端主筋の圧縮応力度は 常温強度の 2 割程度しかなく（図 22）、耐力への寄与率はあまり大き くはない。下端主筋は負曲げモーメントを受ける R C スラブの耐火 性能に少なからず影響し、耐火時間を長くする効果があることを確 認した。

\section{4.まとめ}

負曲げモーメントを受けるR C スラブの耐火性能を実験と解析に より検討した結果、以下の結論が得られた。

(1) 実験の結果、R C スラブは負曲げモーメントに対して高い耐火 性能を有していることが明らかになった。構造設計上の最大荷 重を上回る高い荷重を受けた状態でも長時間にわたり荷重を保 持することが可能である。

(2) 主筋配筋とスラブ厚は負曲げモーメントを受けるR Cスラブの 耐火性能に大きく影響することを確認した。

(3) 数值解析を行った結果、解析值は実験值と良好な対応を示した。 
解析により負曲げモーメントを受ける R C スラブの耐火性能を 評価できることを確認した。

(4) 解析により得られた応力度分布の推移から負曲げモーメントを 受けるR C スラブが火災加熱で破壊に至る挙動を明らかにした。

(5) 荷重比（常温時の終局曲げ耐力に対する作用曲げモーメントの 比）とスラブ厚が同じ場合、上端主筋量が多くなる程、耐火時 間が短くなることを確認した。

(6) スラブ厚が $200 \mathrm{~mm}$ 以下の範囲では、荷重比と主筋配筋が同じ 場合、スラブ厚が大きくなる程、耐火時間が長くなることを確 認した。

(7) 上端主筋の温度上昇は緩やかであり、上端主筋（引張側主筋） の強度低下が負曲げモーメントを受ける R C スラブの火災時耐 力に及ぼす影響は小さいことを確認した。

(8) 解析によるパラメータースタディを行い、主筋配筋とスラブ厚 が耐火性能に与える影響を確認するとともに、荷重比と耐火時 間の関係を明らかにした。

(9) 下端主筋は耐火性能に影響し、耐火時間を長くする効果がある ことを確認した。

本論文で報告した検討は、両端を拘束されることで発生する拘束 曲げモーメントの影響を考慮していない。現在、両端拘束モデルに 対する実験及び解析による研究を行っているところであり、その結 果については報を改めて報告する予定である。

冒頭で述べたように、本研究は実務設計で利用可能な火災耐力評 価法の提案を目標としている。本論文では、数值解析によって負曲 げモーメントを受ける R C スラブの火災時耐力を評価出来ることを 示した。しかし、数值解析による評価は煩雑であり、実務の設計で 逐一行うことは難しい。現在、本論で得られた知見を基に、実務設 計で汎用的に利用出来る火災耐力評価法の研究を行っているところ であり、その結果についても報を改めて報告する予定である。
謝辞

本研究を遂行するにあたり、東京理科大学 $\mathrm{COE}$ 火災科学コースにお いて、若松孝旺教授、上杉英樹教授、鈴木弘之教授、衣笠秀行教授、 古平章夫氏、池田憲一氏から貴重なアドバイスを戴きました。ここ に記して謝辞を表します。

\section{参考文献}

1）西村俊彦，上原茂男: RCスラブが正曲げモーメントを受ける場合の耐火性能 に関寸る研究, 日本建築学会構造系論文集 第 73 巻 第 626 号, pp.677-684, 2008.4

2）西村俊彦，上原茂男: $R C$ スラブの耐火性能に関する研究，日本建築学会大会 学術講演梗概集 A-2, pp.77-78, 2007.8

3）国土交通省住宅局建築指導課ほか:2001 年版耐火性能検証法の解説及び計 算例とその解説，井上書院，2001.3

4) 原田有:建築耐火構法, 工業調査会, 1973

5）斎藤光: 材端拘束鉄筋コンクリート部材の火災時の性状，日本建築学会大会 学術講演梗概集 pp.761-762, 1968.10

6) Hikaru Saito:Behavior of End Restrained Concrete Member in Fire, B.R.I Reserch Paper, No.32, 1968

7) H.Saito, H.Uesugi, M.Yamaguchi, A.Kodaira :Thermal Stress and Deformation of Steel Structures of High Rise Buildings in Fire", FIRE SAFETY SCIENCE Proceedings of The Second International Symposium, pp.719-728, 1988

8) H.Ohashi and A.Kodaira:Calculation of Load and Deformation Behavior of Structure Elements Taking into Account 3-Dimensional Heat Flow, FIRE SAFETY SCIENCE Proceedings of The Fifth International Symposium, pp.1021-1032, 1997

9) Anderberg, Y. and Thelandersson, S.: Stress and Deformation Characteristics of Concrete at high Temperatures, 2. Experimental Investigation and Material Behavior Model, Division of Structural Mechanics and Concrete Construction, Lund Institute of Technology , Bulletin No.54, Lund, Sweden, 1976

10) EUROCODE4, Design of Composite Steel and Concrete Structure, Draft for Part1.2: Structural Fire Design, CEN/TC250/SC4 N56 prENV 1994-1-2

(2008年 9 月 9 日原稿受理，2009年 1 月29日採用決定） 